\title{
A noção de verdade e a circulação do conhecimento científico em Fleck: elementos para uma reflexão sobre a era da pós-verdade
}

\author{
Marcia Tiemi Saito ${ }^{1}$ \\ Instituto Federal do Paraná \\ Foz do Iguaçu - PR
}

\section{Resumo}

Os debates em torno da pós-verdade têm abrangido desde aspectos filosóficos e histórico-sociais, passando por questões linguísticas, psicológicas e axiológicas, até implicações éticas e políticas. O objetivo deste trabalho é buscar compreender o fenômeno da pós-verdade, a partir da epistemologia de Ludwik Fleck, e refletir sobre as possíveis implicações para a Ciência e para a Educação científica. Para isso, serão exploradas a noção de verdade e a descrição dos processos de circulação do conhecimento científico em Fleck. Conclui-se que a perspectiva fleckiana pode ser uma alternativa interessante para se pensar o fenômeno da pós-verdade. Para esse autor, existe uma relação de autoridade, confiança e dependência mútua entre o saber especializado e o saber popular. Seria importante manter essa relação nesse formato, a fim de preservar a democracia politica e evitar o surgimento de movimentos de caráter dogmático e antidemocrático. Também parece ser importante buscar limitar a disseminação de ideias que podem ameaçar o caráter democrático da ciência e a sua própria existência. Por fim, uma popularização da ciência e uma educação cientifica que abrangessem a complexidade da construção do conhecimento cientifico poderiam contribuir para formar visões sobre ciência menos suscetíveis aos efeitos nocivos da pós-verdade.

Palavras-chave: Estilo de Pensamento Científico; Circulação do Conhecimento; Popularização da Ciência; Educação Científica; Relativismo; Democracia.

\footnotetext{
${ }^{+}$Fleck's notion of truth and the circulation of scientific knowledge: elements to think about the post-truth era

* Recebido: junho de 2020. Aceito: agosto de 2020.

${ }^{1}$ E-mail: marcia.saito@ifpr.edu.br
} 


\begin{abstract}
Debates on post-truth have been discussing its different aspects, since its philosophical, social and historical aspects, passing through linguistic, psychological, and axiological issues, until its political and ethical implications. The aim of the present work is try to understand the posttruth phenomenon, based on Ludwik Fleck's epistemology, and reflect on its implications to science and science education. For this, we explore Fleck's notion of truth and his description of circulation of scientific knowledge processes. We conclude that Fleck's perspective can be an interesting alternative to think about the post-truth phenomenon. For Fleck, there is a relationship of authority, trust, and mutual dependency between specialized and popular knowledge. It is important to maintain this relationship with these aspects to preserve democracy and avoid the emergence of dogmatic and antidemocratic social movements. It also seems important to limit dissemination of ideas, which can be dangerous for the democratic aspect of science and for its own existence. Finally, a popularization of science and a scientific education which discuss the whole complexity of the construction of scientific knowledge can better contribute to form images about science less susceptible to the harmful effects of post-truth.
\end{abstract}

Keywords: Scientific Thought Style; Circulation of Knowledge; Science Popularization; Science Education; Relativism; Democracy.

\title{
I. Introdução: explorando a era da pós-verdade
}

A pós-verdade tem sido tema de grandes debates nos últimos anos, em diversas áreas do conhecimento e da cultura. A escolha desse termo como a palavra do ano, em 2016, pelo dicionário Oxford, reflete a relevância que esta temática adquiriu. Desde então, os debates em torno da pós-verdade têm abrangido desde os seus aspectos filosóficos e histórico-sociais, passando por questões linguísticas, psicológicas, axiológicas e estratégicas, até as suas implicações éticas e políticas. Essa grande gama de aspectos evidencia a complexidade das questões relacionadas a este tema, que pode ser percebida nas diferentes tentativas de se caracterizar este fenômeno apresentadas a seguir.

Em primeiro lugar, a caracterização da pós-verdade como um fenômeno se justifica, entre outros fatores, pela popularidade que este termo adquiriu nos últimos anos, passando de um termo periférico a um termo constantemente citado nos comentários sobre política (MCCOMISKEY, 2017). Essa popularidade seria o resultado de um longo processo de circulação de diferentes ideias e concepções filosóficas. De acordo com McComiskey (2017, 
p. 5-6), no senso comum, a pós-verdade significaria um estado no qual a linguagem carece de referências a fatos, verdades e realidades, se tornando um meio puramente estratégico. McIntre (2018, p. 5-6), por sua vez, destaca que o termo "pós-verdade" não está relacionado somente à mentira ou a uma jogada política, mas que denota uma preocupação com o conceito de verdade e com um sentimento de que ela estaria sob ataque, indicando que, de alguma forma, a pós-verdade estaria relacionada a uma situação de conflito ou disputa. Dessa forma, para McIntre (2018, p. 9), a pós-verdade, em sua forma mais pura, seria quando se acredita que a reação da massa teria o poder, de fato, de mudar os fatos sobre uma suposta mentira.

Também ressaltando esse caráter de disputa, Sim (2019, p. 165) dá destaque às questões éticas, políticas e sociais em torno desse fenômeno, ao considerar que a pós-verdade seria um movimento ideológico, enraizado na noção de contrariedade, profundamente antidemocrático em seu caráter, e comprometido em gerar divisões na sociedade, a fim de ganhar vantagens políticas. Fuller (2018, p. 53), por sua vez, destaca os aspectos axiológicos e estratégicos da pós-verdade, ao caracterizá-la como parte de uma espécie de jogo, que busca mudar as suas regras em prol de benefício próprio. Nesse sentido, a pós-verdade seria uma postura reconhecidamente construtivista social, na qual muitos argumentos buscam implementar "fatos alternativos" ou estabelecer uma "ciência alternativa" às instâncias socialmente reconhecidas, visando esse benefício. O autor também caracteriza a pós-verdade como um processo ambíguo, que envolveria o desencantamento com a autoridade científica, acompanhado de um reencantamento com a ciência, como uma forma de conhecimento que molda a vida das pessoas. Fuller (2018, p. 107-112) também ressalta o papel da imprensa, do jornalismo, da circulação do conhecimento e da democratização do acesso a ele e descreve como isso permitiu com que os seus seguidores decidissem por si mesmos o que acreditariam ou não, de acordo com as suas visões de mundo particulares. Por fim, Nichols (2017, p. 4-5) analisa com mais detalhe as relações sociais entre especialistas e o público leigo, e relaciona a era da pós-verdade com o que ele denomina de "a morte da competência". Este termo, segundo o autor, não se refere à morte do conhecimento especializado em si, mas a uma quebra de confiança nos especialistas e às dificuldades no diálogo e na circulação das ideias entre estes e a comunidade mais ampla. De acordo com o autor, a confiança nos especialistas passou a ocorrer somente do ponto de vista técnico e o conhecimento passou a ser considerado algo com importância exclusivamente prática, a ser utilizado convenientemente, conforme o desejo e a necessidade. Assim, "a morte da competência" não seria somente uma rejeição ao conhecimento existente, mas fundamentalmente uma rejeição à ciência e à racionalidade objetiva, que consistiriam nos fundamentos da civilização moderna.

Diante dessa diversidade de aspectos levantados pelas diferentes tentativas de se caracterizar o fenômeno da pós-verdade, a fim de compreendê-lo mais profundamente, tornase relevante questionar: quais são as origens e influências filosóficas e histórico-sociais desse fenômeno? Como essas influências se apresentam concretamente? Quais as suas implicações sociais, políticas e éticas? 
Em termos de aspectos filosóficos, a pós-verdade parte primordialmente de questionamentos acerca da noção de verdade e sobre a possibilidade de se estabelecer um critério que pudesse garantir a verdade de uma proposição. Esses questionamentos existem desde o início da filosofia ocidental, quando alguns filósofos da Grécia Clássica argumentavam que esse critério talvez nunca pudesse ser encontrado. Isso significaria que o máximo que se poderia atingir seriam graus de verdade ou crenças de maior ou menor grau de utilidade. Essa era a posição dos filósofos do ceticismo clássico, a qual foi circulando e se propagando ao longo da história e, atualmente, exerce uma importante influência no fenômeno da pós-verdade. Nessa concepção, a verdade deveria ser tratada como um conceito relativo e não absoluto, com todas as dificuldades que isso implicaria (SIM, 2019, p. 4-5). Sócrates, por outro lado, nos alertava sobre os perigos das afirmações falsas para o conhecimento, ao afirmar que a ignorância era remediável: se alguém é ignorante, pode ser ensinado, porém, a grande ameaça vem daqueles que acreditam que já conhecem a verdade e que seriam impelidos a atuar no âmbito da falsidade. Contudo, independentemente destes debates e das diferentes concepções sobre a noção de verdade, o fato é que há pouca discordância sobre a sua importância (MCINTRE, 2018, p. 6-7).

Outros aspectos filosóficos presentes no fenômeno da pós-verdade são o relativismo e as questões referentes à linguagem e à formulação dos discursos. De fato, muitos filósofos contemporâneos adotaram uma postura relativista em relação à noção de verdade, argumentando que a linguagem seria muito imprecisa para garantir a veracidade de qualquer afirmação. O filósofo pós-estruturalista Jacques Derrida, por exemplo, defendia que o significado deveria ser considerado um constante estado de fluxo, que se alteraria sutilmente de uma declaração a outra, e de um participante a outro, ao longo do tempo e do processo de formulação do discurso. A verdade, nessa concepção, seria uma qualidade variável, nunca fixa ou fixável, que sempre se modificaria, conforme as nossas intenções, e que nunca poderia estar acima de qualquer possibilidade de dúvida. A consequência desse tipo de argumento seria a de que nenhum valor de julgamento poderia ter maior validade do que qualquer outro, não haveria, portanto, nenhuma forma de decidir entre eles de forma lógica. Para o filósofo pós-moderno Jean-François Lyotard, por sua vez, nós temos pelo menos alguma capacidade de discriminar entre utilidade ou o valor dos julgamentos, contudo, nada pode ser definido de outra forma a não ser ad hoc (SIM, 2019, p. 5-6). Por fim, o filósofo da ciência Bruno Latour, ao defender a universalização do seu princípio de simetria indistintamente, também acabou por relativizar o conhecimento científico, pois abriu margem para que se considerassem as afirmações de criacionistas, de céticos em relação às questões climáticas, da medicina New Age, etc., com o mesmo valor epistemológico das afirmações científicas (FULLER, 2018, p. 61). Com isso, as defesas destes pensadores, ao circularem no meio sociocultural, também terminaram por exercer alguma influência no advento do fenômeno da pós-verdade. De fato, Zackariasson (2018, p. 2-3) afirma que o relativismo e a pós-verdade são fenômenos correlacionados, pois ambos emergem e se alimentam de um crescente ceticismo sobre a 
capacidade dos sujeitos de adquirirem conhecimento fora das condições locais, pontos de vista, ideologias, conceitos, teorias, relações de poder, entre outros fatores, os quais mediam e permeiam qualquer forma de questionamento. Assim, o autor denomina de "dinâmica da relativização" a crescente conscientização do papel formativo que a linguagem, os conceitos, teorias e interesses exercem em práticas aparentemente inocentes como a experiência, a percepção e a aquisição de conhecimento. Nesse contexto, para o autor, a condição da pósverdade seria aquela que desistiu da ideia de "verdade" no singular como o ponto final de um questionamento e, em vez disso, considera a política, a ciência e outros campos, como consistindo de batalhas entre diferentes regimes de verdade, os quais visam dominar a sua respectiva agenda. Contudo, para Sim (2019, p. 168), mesmo que tenhamos que reconhecer que a verdade sempre será uma entidade problemática, o relativismo não deveria ser uma barreira para sua busca. Assim, para o autor, a condição posta pela pós-verdade nos desafia a encontrar formas pragmáticas de contornar as lacunas da absoluta certeza, para buscar pelo menos algum grau de confiabilidade.

Para além do relativismo e dos questionamentos em relação à verdade, no fenômeno da pós-verdade, há também a influência de questões filosóficas referentes à retórica e à subversão da verdade, que inevitavelmente tocam em aspectos éticos. De acordo com McComiskey (2017, p. 6-8), a retórica fundamentalmente lida com argumentos e opiniões razoáveis, não com fatos incontestáveis, realidades fundamentais ou verdades universais. Segundo o autor, em sua essência, aqueles que se utilizam da retórica devem saber os fatos a fim de deturpá-los por meio de mentiras; devem reconhecer a verdade, a fim de enganar as pessoas por meio de falácias; e devem compreender a realidade a fim de manipulá-la por meio de argumentos. Assim, em princípio, a retórica pode se utilizar de estratégias de caráter reconhecidamente antiético, a fim de comparar injustamente opiniões com fatos, realidades e verdades. McIntre (2018, p. 7-8), por sua vez, explora os diferentes níveis e formas de subverter a verdade, presentes no fenômeno da pós-verdade, não exclusivamente ligados à retórica. O primeiro nível seria quando se comete o erro de dizer uma inverdade, sem a intenção de fazê-lo; o segundo seria a ignorância voluntária ou displicência, que ocorre quando não sabemos se algo é verdade, mas o dizemos ou propagamos mesmo assim, sem nos importarmos em verificar se a informação é correta; por fim, estaria a mentira, quando dizemos uma inverdade intencionalmente, a fím de enganar alguém. Quando a intenção é manipular alguém para que essa pessoa acredite em algo que sabemos não ser verdade, passamos do campo da mera "interpretação" dos fatos para a sua falsificação. Dessa forma, para Tallis (2016, p. 8), de forma geral, em suas diferentes formas de atuação, o objetivo do discurso da pós-verdade se tornou a "desestabilização ou até mesmo a destruição da noção de verdade como tal".

Em termos histórico-sociais, por sua vez, diversos autores procuram localizar processos históricos importantes na constituição do fenômeno da pós-verdade. Zackariasson (2018, p. 2-8) chama a atenção para como, após a era da modernização, a crescente 
familiaridade com outras culturas, religiões e linguagens, por meio da circulação das ideias, do conhecimento e das pessoas, nos levaram à consciência do quanto as normas que regulam as interações sociais e os julgamentos que fazemos são dependentes do contexto e, portanto, possuem uma validade limitada. Por outro lado, também houve um movimento de se reconhecer os graves danos causados por uma ciência positivista e reducionista, pelo absolutismo, pela intolerância e outras formas de imperialismo cultural, moral, epistemológico, econômico e outros casos, nos quais as afirmações se revestiram de uma "verdade universal" e em que o conhecimento serviu, em última instância, para fins de opressão e colonialismo. Esse processo também nos levou a reconhecer a importância da diferença e do caráter contingente dos nossos propósitos, práticas, julgamentos e crenças. Dessa forma, o autor ressalta que não surpreende o fato de que o relativismo tenha sido associado à tolerância e se tornado um importante argumento nos dias atuais. Apesar de, em realidade, não haver nada de inerente nele que, de fato, implicaria que devamos ser mais tolerantes com o diferente. Nichols (2017, p. 5-10), por outro lado, destaca como a conquista de direitos, a democratização do acesso à informação e o movimento de universalização da educação foram seguidos de um processo de mercantilização. Para o autor, até o início do século XX, havia menos conflitos entre especialistas e leigos, porque a participação na vida política, intelectual e científica era muito restrita. Os debates sobre ciência, filosofia e políticas públicas ocorriam somente em pequenos círculos de pessoas que tiveram acesso à educação. Somente na segunda metade do século XX, é que mudanças sociais quebraram as barreiras de raça, classe, gênero e, particularmente, entre cidadãos não educados e uma elite de especialistas. Por um lado, esse círculo mais amplo de circulação e debate de ideias significou mais conhecimento, mas por outro, também significou mais atritos sociais. Assim, a educação universal, o empoderamento das minorias, o crescimento da classe média e da mobilidade social colocaram a minoria de especialistas e a maioria dos cidadãos em contato direto, após cerca de dois séculos de pouca interação. De acordo com o autor, o resultado não foi um maior respeito pelo conhecimento, mas o crescimento de uma convicção irracional de que todos seriam igualmente competentes para opinar sobre qualquer assunto. Isso porque, paralelamente a esse processo, a educação passou a ser vista como uma mercadoria e os estudantes tratados como clientes em vez de aprendizes. Isso fez com que eles adquirissem uma maior autoestima, porém com um menor apreço pelo conhecimento e não desenvolvessem o hábito do pensamento crítico, que os permitiria a continuar aprendendo e avaliando cuidadosamente questões complexas, com as quais eles teriam que lidar e opinar como cidadãos. O jornalismo e a divulgação científica também passaram a enfrentar novos desafios, tendo que lidar com cidadãos que também tratam as notícias e o conhecimento como mercadoria, e que demandam mais por serem entretidos do que bem informados. Com isso, a nova indústria do jornalismo passou a ter que elaborar reportagens mais atrativas, chamativas e entretecedoras, para que pudessem adquirir audiência suficiente. Dessa forma, o autor relata o advento dos "céticos da autoridade" e dos "seguidores da superstição", no final do século 
XX. Nesse processo, em um mundo orientado pela informação, os cidadãos acreditam que são especialistas em tudo, e parecem acreditar que ter direitos igualitários do ponto de vista político também significa que a opinião de qualquer pessoa sobre qualquer assunto deva ser aceita como igualmente válida, em qualquer situação. McIntre (2018, p. 21-33), por sua vez, dá destaque ao papel dos interesses econômicos e políticos no advento do negacionismo da ciência, e a como este tem sido um caminho utilizado para o fortalecimento da pós-verdade. De acordo com o autor, esse fenômeno teve início nos anos 1950, com a indústria do tabaco, que buscava negar as evidências de que o fumo poderia causar câncer. Ele também foi marcado pela negação da existência e da influencia da atividade humana no aquecimento global. Ambos os casos foram movidos por interesses econômicos e políticos. Assim, o autor mostra como a estratégia de ressaltar os conflitos de interesses, o financiamento das pesquisas, as discordâncias na interpretação de resultados e outros fatores existentes na elaboração do conhecimento científico, tem sido utilizada para questionar a competência dos cientistas e atuado como verdadeiras campanhas de desinformação.

Diante desse contexto histórico, diversos autores exploram os perigos que a pósverdade pode trazer para as sociedades democráticas, do ponto de vista político. Para Sim (2019, p. 155-169), a pós-verdade não pode ser considerada como parte aceitável de qualquer sociedade democrática, as quais deveriam funcionar com base na razão e no respeito aos direitos humanos universais, mais do que na ignorância e em preconceitos. Quando se permite que a ignorância e o preconceito dominem a esfera pública, corremos o risco de ser manipulados por demagogos com o poder de influenciar a sua audiência emocionalmente, e que poderiam comprometer os direitos humanos e o interesse público, para atingir objetivos particulares. Quando esse cenário se desenvolve, a morte da democracia se torna uma ameaça real. Nichols (2017, p. 216-238) segue a mesma linha de pensamento, ao ressaltar que a relação entre especialistas e cidadãos, como todas as relações em uma democracia, é construída em torno da confiança. Quando essa confiança é quebrada, especialistas e leigos se tornam facções conflitantes e a democracia corre o iminente perigo de cair tanto nas regras ditadas pela multidão, quanto em uma tecnocracia elitista. Nesse processo, a ignorância, o anti-intelectualismo e o desengajamento do público se tornam armas perigosas, porque uma democracia estável, em qualquer cultura, se sustenta quando o público realmente entende as consequências das suas próprias escolhas. Dessa forma, pode-se dizer que a relação entre especialistas e cidadãos não é "democrática", no sentido de um estado verdadeiro de igualdade. Democracia, em sua visão, denota um sistema de governança. Contudo, quando uma democracia é entendida como uma demanda sem fim por um imerecido respeito em relação a opiniões infundadas, qualquer coisa se torna possível, inclusive, o seu próprio fim. Em contrapartida, Zackariasson (2018, p. 2-13) pondera que, se desejarmos refletir sobre como navegar com cautela sobre uma espécie de condição da pós-verdade, a fím de evitar abusos dos diferentes lados, devemos transcender as caricaturas entre relativistas e universalistas, e aprender mais sobre como as questões relacionadas ao relativismo surgem e 
funcionam nos diferentes contextos. De acordo com o autor, também devemos pensar em uma melhor articulação para legitimar as preocupações colocadas por ambos os lados, e refletir sobre quais formas de diferenças - incluindo aquelas intratáveis - poderíamos e deveríamos aprender a conviver e quais tipos de diferenças não deveríamos tolerar.

Assim, diante da complexidade e da amplitude dos aspectos que perpassam a pósverdade e suas implicações, nota-se a existência de duas temáticas centrais: os debates em torno da verdade e da circulação do conhecimento científico. Dessa forma, o objetivo do presente trabalho é buscar compreender o fenômeno da pós-verdade, a partir da epistemologia de Ludwik Fleck, a fim de refletir sobre as possíveis implicações e desafios que esse fenômeno traz para a Ciência e para a Educação Científica. Em particular, será explorada a noção de verdade em Fleck e como esse autor descreve os processos de circulação do conhecimento, em especial, o conhecimento científico.

A pertinência da perspectiva fleckiana para essa análise e os motivos para a sua escolha como referencial teórico se devem a diversos fatores. O primeiro deles é que a sua própria trajetória profissional e a evolução do seu pensamento nos fornecem pistas acerca das limitações do que Fleck considera ser o "caráter democrático da ciência” (FLECK, [1929] 1986; FLECK, [1936] 1986). Em particular, destaca-se o fato de que o próprio pensamento do filósofo polonês chegou a ser deturpado e utilizado para defender fins, contra os quais ele se contrapunha veementemente. Dessa forma, o contexto e a obra de Fleck tocam na questão dos problemas existentes entre a ampla abertura do coletivo de pensamento da ciência, em contextos de conflitos de interesse, e a possibilidade de desenvolvimento de um ceticismo exacerbado e de deturpações do conhecimento científico. Outro motivo é que a sua obra é considerada relativista em relação à construção do conhecimento científico, por muitos pensadores, inclusive, por alguns de seus contemporâneos. Contudo, o próprio Fleck responde a essas acusações, em trechos de sua obra. Com isso, a sua obra também acaba tocando no problema do relativismo na ciência. Por fim, em correspondências com seus contemporâneos, Fleck chega a reconhecer que, em determinados contextos ideológicos, a popularização da ciência poderia sofrer com as contradições destes e acabar sendo utilizada para fins nefastos, do ponto de vista político-social. No entanto, ainda assim, ele demonstra confiança na possibilidade de se construir um conhecimento comum, baseado nos valores da ciência, o qual poderia contribuir para uma sociedade mais tolerante e democrática. Todos esses motivos, de alguma forma, se relacionam com o fenômeno da pós-verdade e suas implicações, e serão mais bem detalhados na próxima seção.

\section{O contexto e a obra de Fleck: elementos para pensar a pós-verdade}

A trajetória pessoal e profissional do filósofo da ciência, médico e pesquisador em microbiologia Ludwik Fleck (1896-1961) é marcada por vivências e necessidades de adaptação a diferentes e adversos contextos. Fleck nasceu em família de origem judia, na cidade de Lwów, à época, pertencente à Polônia e atualmente à Ucrânia. Durante a Segunda 
Guerra Mundial, foi deportado pelos nazistas para o gueto judeu de sua cidade e, posteriormente, foi preso e obrigado a trabalhar no desenvolvimento de vacinas contra tifo em laboratórios, nos campos de concentração de Auschwitz e Buchenwald, nos anos de 1943 e 1944, respectivamente. Fleck conseguiu sobreviver à guerra e faleceu de câncer em 1961, em Israel (SCHÄFER; SCHNELLE, 2010). Profissionalmente, nos anos que precederam as suas reflexões epistemológicas, Fleck experimentou várias mudanças abruptas em seu local de trabalho, tendo que se adaptar a diferentes contextos profissionais - de laboratórios de pesquisa e diagnóstico a hospitais locais - e colaborar com diferentes pessoas, de diferentes interesses e especialidades, para realizar sua pesquisa imunológica. Assim, as repetidas transições entre diferentes espaços sociais, dentro da ciência, apresentaram a Fleck a significância epistêmica de sua estrutura social (FAGAN, 2009, p. 278-279). Por conta disso, Löwy (1990) defende que o próprio desenvolvimento histórico de Fleck na ciência foi a sua principal motivação epistemológica para formular uma filosofia inovadora, que busca estabelecer uma interdependência entre a estrutura social e as normas epistêmicas na ciência.

Em relação à repercussão inicial de sua obra filosófica, diferentemente do que normalmente se conta, a sua monografia Gênese e desenvolvimento de um fato científico, de 1935, foi amplamente discutida, nos anos anteriores ao início da Segunda Guerra Mundial. De fato, a sua obra não se tornou parte do círculo esotérico de especialistas no campo da epistemologia, durante o período de sua vida. Porém, Fleck chegou a realizar discussões com o filósofo Izydora Dambska, em 1937, e com o historiador da medicina Tadeusz Bilikiewicz, em 1939. Além disso, foram realizadas cerca de 20 resenhas críticas, nos anos seguintes à publicação do seu livro, em diversos países. Dentre estas resenhas e comentários críticos, destacam-se duas, ambas publicadas em 1936: uma por Hans Petersen, um anatomista alemão, e outra de Oswald Kroh, um psicólogo alemão, que posteriormente se tornou líder de uma seção do projeto do partido nazista de Hitler (FEHR, 2012). Petersen mostrou grande interesse pela noção fleckiana de "estilo de pensamento", por essa noção estabelecer uma ligação entre uma forma de pensar específica com a situação histórica e o movimento geral da cultura. Com isso, esse autor interpreta que Fleck, de alguma forma, daria suporte a uma espécie de "estilo de pensamento alemão", que estaria surgindo naquele contexto. Kroh, por sua vez, cogita a possibilidade futura de incluir a "determinação racial" na noção de "estilo de pensamento", ao afirmar que esta consiste em uma:

(...) abordagem fecunda, que afasta a chamada imparcialidade do pensamento cientifico, (...) [e] traz sugestões de como lidar com outros problemas científicos em estudos de casos históricos, uma questão que pode ser frutífera para a psicologia e a epistemologia, particularmente, sobre se a determinação racial de um estilo de pensamento é levada em conta (KROH, 1936, p. 164 apud FEHR, 2012, tradução livre).

Nesta passagem, Kroh ressalta a não imparcialidade do pensamento científico, a fim de deliberadamente transformá-la em um argumento, para sustentar pesquisas de interesses 
político-ideológicos racistas, disfarçados sob uma roupagem de "problemas científicos". Fleck respondeu a esses comentários, no âmbito das suas discussões com Tadeusz Bilikiewicz, em 1939, e versou sobre a forma em que seu pensamento foi apropriado e usurpado politicamente (FEHR, 2012). Nessas discussões, ele chega a fazer referência explícita aos "tempos turbulentos atuais", ao afirmar que:

(...) políticos astutos transformam o mais rápido possivel as novas informações em slogans demagógicos. A natureza sociológica e coletiva do conhecimento primeiramente se tornou um slogan político, fazendo referência ao condicionamento social e de classe da ciência e, então, as correntes políticas concorrentes criaram o espírito de nação e de raça para proporcionar uma visão de mundo mítica a ser propagada ao longo dos tempos (FLECK, [1939] 1990, pp. 250-251, tradução livre).

Seria também contra esse contexto, que se devem considerar as repetidas referências e defesas de Fleck, entre 1929 e 1939, ao caráter genuinamente democrático do "pensamento típico das ciências naturais", as quais foram totalmente omitidas nos comentários de Kroh e seus colegas. Curiosamente, porém, em seus escritos após 1939, Fleck deixa de utilizar a expressão "democrática", para se referir à ciência. Considerando os eventos e pontos de virada na história da civilização, que formaram a sua biografia, e as catástrofes políticas que Fleck teve que vivenciar, seria possível cogitar que ele teria recuado de suas posições anteriores, ou perdido a sua confiança em que a democracia de fato existia no funcionamento das ciências. Contudo, em seu texto intitulado Crise na ciência: por uma ciência livre e mais humana, escrito em Israel, após meados dos anos 1950, e não publicado durante a sua vida, Fleck faz um alerta contundente aos cientistas sobre os perigos inerentes da propaganda, que claramente remete à sua posição dos anos 1930. De qualquer forma, aparentemente, a própria biografia de Fleck nos pode fornecer importantes pistas de onde poderiam estar os limites do caráter democrático do sistema de funcionamento da ciência, defendido pelo filósofo polonês (FEHR, 2012), os quais podem estar relacionados à apropriação do conhecimento e sua utilização para fins anticientíficos e, portanto, antidemocráticos na perspectiva fleckiana.

Outro aspecto interessante da obra fleckiana para o estudo da pós-verdade é que o filósofo polonês é considerado por muitos um pioneiro das ideias relativistas e construtivistas na filosofia da ciência (SEIDEL, 2011). Os próprios contemporâneos de Fleck também consideraram a sua filosofia como uma defesa de um relativismo inaceitável, que atribuiria a mesma importância a várias imagens da realidade, provenientes de diferentes estilos de pensamento, mesmo que essas imagens fossem inconsistentes. Bilikiewics, por exemplo, foi um dos que argumentou que a filosofia fleckiana seria incapaz de estabelecer um critério geral de verdade, pois, de acordo com ele, se os conceitos de verdade e realidade são relativos a um estilo de pensamento, nenhuma imagem do mundo poderia ser considerada melhor ou pior do que outra: todas poderiam igualmente ser consideradas verdadeiras ou reais. Porém, o próprio Fleck respondeu a essas críticas. Ele admite que a teoria dos estilos de pensamento não 
estabelece um critério geral de verdade, mas argumenta que isso não implica em um relativismo epistemológico (FAGAN, 2009; SEIDEL, 2011). Fleck rejeita a posição de Bilikiewicz e de outros críticos que pressupõem a existência de uma "realidade objetiva" absoluta, que consistiria em uma "essência da ciência" a ser descoberta. Ele também rejeita qualquer posição filosófica que desconsidera o condicionamento social dos sujeitos. Ele, portanto, exclui a possibilidade de contextos de justificativa ahistóricos, porém não exclui a justificativa em si, a qual, em sua epistemologia, é fortemente embasada na crença firme nos métodos da ciência, a qual ele considera um caminho para a democracia. Esta postura e o seu comprometimento com a objetividade científica, portanto, o afasta das considerações construtivistas mais recentes sobre o conhecimento científico e da maioria das formas de idealismo e relativismo. De fato, a maioria das atitudes de julgamento associadas ao construtivismo social se preocupa com a transformação ou a depreciação daquilo que é revelado como um resultado contingente dos processos sociais (GOLINSKI, 2005). A epistemologia de Fleck também visa à transformação do conhecimento, porém ele, como um cientista que nunca abandonou a sua carreira científica, a concebe como um resultado do questionamento, especificamente do questionamento científico, conforme as normas da objetividade. Um questionamento guiado por essas normas, de acordo com o ideal tradicional de verdade objetiva, clareza e precisão, produz mudanças graduais e contínuas no estilo de pensamento. Sua epistemologia, portanto, é uma extensão reflexiva do questionamento científico moderno, conforme o ideal de objetividade científica, mais do que uma intervenção puramente sociológica ou política. Assim, a posição epistemológica de Fleck é avaliativa, reflexiva, exemplificativa de sua própria prática e distinta tanto do relativismo, quanto do absolutismo epistemológico (FAGAN, 2009).

O último aspecto acerca do pensamento fleckiano, que chama a atenção por conta da relação e das similaridades com aspectos do fenômeno da pós-verdade, é o fato de que o filósofo polonês chega a reconhecer o perigo da popularização da ciência, em contextos ideológicos adversos à crítica. Para ele, uma "análise epistemológica da ciência popular (...) ainda está por ser feita" (FLECK, [1935] 2010, p. 165-166). De fato, diante da ascensão do nazismo e na iminência da Segunda Guerra Mundial, em correspondências com seus contemporâneos, Fleck chega a afirmar:

Nós estamos diante de um estranho fenômeno, que envolve uma crise ideológica e um desencorajamento entre os especialistas e, ao mesmo tempo, o interesse pela ciencia cresceu entre o público em geral, o que é refletido na demanda crescente por livros de divulgação científica. Esse não é um fenômeno sem consequências, principalmente porque, nessas condições, a popularização da ciência tem se tornado um domínio de pessoas incompetentes (FLECK, [1939] 1990, p. 255, tradução livre).

No entanto, mesmo diante desse contexto, em seus escritos anteriores a 1939, Fleck parece não perder a confiança na possibilidade de se construir um conhecimento e um 
coletivo de pensamento comum e mais tolerante, ao propor uma epistemologia comparada, de caráter científico. Apesar de, por um lado, Fleck ser notoriamente otimista, sobre o poder subsequente de sua epistemologia comparada, por outro, ele reconhece que a possibilidade de se explorar o conhecimento sobre o condicionamento social do pensamento, para fins viciosos, poderia resultar em consequências políticas devastadoras. Assim, por vezes, o filósofo polonês parece acreditar que o sucesso de sua epistemologia comparada seria, em realidade, de alguma forma, uma necessidade histórica. Fleck, de fato, espera que investigações sociológicas comparativas aumentem a "tolerância em relação a estilos de pensamento alheios", impeçam que "dogmatismos de fanáticos de seu próprio estilo de pensamento causem conflitos com pessoas de um estilo de pensamento diferente" e que "nos imunize contra a submissão absoluta a propaganda". Dessa forma, assim como a ciência, a epistemologia comparada dos estilos de pensamento seria, para Fleck, um empreendimento sem fim, que visaria construir uma sociedade mais democrática e tolerante, sintetizando diferentes pontos de vista e dissolvendo particularismos. Dessa forma, Fleck aparentemente estava convencido de que a sua nova ciência do conhecimento nos conduziria a uma compreensão mútua e, portanto, a uma verdade e objetividade comuns, não absolutas, porém sintetizadas (SEIDEL, 2011).

Sendo assim, diante dos aspectos gerais da epistemologia fleckiana apresentados, nas próximas seções, será explorada com maior profundidade a noção de verdade em Fleck, e como esse autor descreve os processos de circulação do conhecimento científico, a fim de refletir melhor sobre os aspectos e o funcionamento do fenômeno da pós-verdade. Por fim, a partir dessas análises, se realizará uma reflexão sobre as possíveis implicações e os desafios que esse fenômeno traz para a Ciência e para a Educação científica.

\section{A noção de verdade em Fleck: caminhos entre o relativismo e o absolutismo epistemológicos}

Conforme explorado na primeira seção deste trabalho, o fenômeno da pós-verdade decorre de um longo processo de relativização e de um ceticismo crescente em relação à noção de verdade. Por um lado, esse processo foi importante, por considerar aspectos histórico-sociais, que inevitavelmente permearão a formulação e a construção do conhecimento, e apontar as limitações da possibilidade de se atingir uma "verdade absoluta" independente dessas condições. Por outro lado, no entanto, trouxe diversas questões e problemáticas a serem contornadas, como a autorrefutação ${ }^{2}$ do relativismo epistemológico e a atribuição de um mesmo grau de confiabilidade às diferentes formas de conhecimento, incluindo aquelas que se contrapõem ou contradizem a ciência.

\footnotetext{
${ }^{2}$ Uma crítica comum ao relativismo epistemológico é que ele seria autorrefutável, ao considerar que não existiriam verdades absolutas. $\mathrm{O}$ argumento é: se não existem verdades absolutas, essa mesma sentença não poderia ser verdadeira.
} 
A concepção de verdade em Fleck é interessante, por procurar, ao mesmo tempo, reafirmar a importância de uma epistemologia que considere os aspectos histórico-sociais na construção do conhecimento e ser uma alternativa ao relativismo epistemológico, ao buscar traçar um caminho intermediário entre este e o absolutismo epistemológico. Dessa forma, nesta seção, será analisada de forma mais detalhada essa concepção e como ela pode contribuir para se pensar o fenômeno da pós-verdade.

A epistemologia fleckiana se coloca em oposição ao neopositivismo do Círculo de Viena, corrente de pensamento hegemônica na filosofia da ciência de sua época, pois se opõe a qualquer epistemologia que desconsidere o condicionamento social da produção do conhecimento. De acordo com ele, "sem esse condicionamento, o conhecimento simplesmente não é possível” (FLECK, [1935] 2010, p. 86). Assim, Fleck se opõe a qualquer teoria do conhecimento que considere o processo do conhecimento como uma relação binária entre sujeito e objeto, defendendo que o respectivo estado do saber deve entrar como terceiro fator fundamental nessa relação. Isso porque as relações históricas e estilísticas presentes no saber necessariamente mediam a interação entre o objeto e o processo do conhecimento, nas suas palavras: "algo já conhecido influencia a maneira do conhecimento novo; o processo do conhecimento amplia, renova e refresca o sentido do conhecido" (FLECK, [1935] 2010, p. 81). Segundo ele, a entidade que propicia o elo entre sujeito e objeto e consiste no portador comunitário das relações histórico-sociais do conhecimento é o coletivo de pensamento, o qual define da seguinte forma:

Se definirmos o coletivo de pensamento como a comunidade das pessoas que trocam pensamentos ou se encontram numa situação de influência recíproca de pensamentos, temos, em cada uma dessas pessoas, um portador do desenvolvimento histórico de uma área de pensamento, de um determinado estado do saber e da cultura, ou seja, de um estilo especifico de pensamento (FLECK, [1935] 2010, p. 82).

A partir dessa definição, então, Fleck chama a atenção para a principal característica do coletivo de pensamento: o seu estilo de pensamento, o qual possui dois aspectos principais e inseparáveis, relacionados à percepção e à ação, e é definido como:

(...) a disposição (Bereitschaft) para um sentir seletivo e para um agir direcionado correspondente. (...) Podemos, portanto, definir o estilo de pensamento como a percepção direcionada em conjunção com o processamento correspondente no plano mental e objetivo. Esse estilo é marcado por características comuns dos problemas, que interessam a um coletivo de pensamento; dos julgamentos, que considera como evidentes e dos métodos, que aplica como meios do conhecimento (FLECK, [1935] 2010, p. 149).

Fleck também identifica características estruturais comuns a todos os coletivos de pensamento, os quais são formados pelos círculos exotérico e esotérico: 
Essa estrutura universal do coletivo de pensamento consiste no seguinte: em torno de qualquer formação do pensamento (...) forma-se um pequeno círculo esotérico e um círculo exotérico maior de participantes do coletivo de pensamento. Um coletivo de pensamento consiste em muitos desses círculos que se sobrepõem, e um indivíduo pertence a vários círculos exotéricos e poucos círculos esotéricos. (...) O círculo exotérico não possui uma relação imediata com aquela formação de pensamento, mas apenas através da intermediação do círculo esotérico. A relação da maioria dos participantes do coletivo de pensamento com as formações do estilo de pensamento reside, portanto, na confiança nos iniciados. Mas até esses iniciados não são, de maneira alguma, independentes: dependem mais ou menos, de maneira consciente ou inconsciente, da "opinião pública", isto é, da opinião do círculo exotérico (FLECK, [1935] 2010, p. 157).

Com isso, no centro do círculo esotérico estariam situados os membros do coletivo de pensamento iniciados há mais tempo em determinada formação de pensamento, ou aqueles que possuem maior confiança e autoridade ao tratar dessa formação. Já no círculo exotérico, estariam situados os membros que também possuem participação na formação desse pensamento, porém de forma mais distanciada. Para ilustrar a relação entre ambos os círculos, Fleck faz uma comparação desta com a relação sociológica entre a elite e as massas: quando a primeira possui uma posição mais forte, ela procura se distanciar e se isolar da multidão, então, os segredos e o dogmatismo passam a dominar no funcionamento do coletivo de pensamento. Nesse caso, a elite "enfatiza a origem sobrenatural das ideias que ela representa, e a sua importância requer obediência e docilidade. (...) Esses coletivos são mais ou menos bem delimitados e conservadores: seus ideais se baseiam em eventos, poderes e revelações que aconteceram no passado" (FLECK, [1936] 1986, p. 103, tradução livre). Para Fleck, esse seria o caso dos coletivos de pensamento religiosos, por exemplo. Por outro lado, quando as massas é que possuem uma posição mais forte frente à elite, essa relação adquire um traço mais democrático, a opinião pública passa a ser lisonjeada e respeitada, e a elite tende a conservar a confiança das massas. Nesse caso, “o maior critério é a 'apreciação de todos'; todos podem e devem discutir cada verdade. Esses coletivos de pensamento possuem limites abertos e aceitam novos membros de bom grado" (FLECK, [1936] 1986, p. 103, tradução livre). Segundo Fleck, essa seria a situação na qual se encontra a maioria dos coletivos de pensamento das ciências naturais. Assim, de acordo com ele, no caso específico dos coletivos de pensamento científicos, a estrutura se organiza da seguinte forma:

O pesquisador altamente qualificado que trabalha de forma criativa num problema (...), ocupa, enquanto "profissional especializado", o centro do circulo esotérico desse problema. Fazem parte desse círculo ainda os pesquisadores que trabalham com problemas afins, na qualidade de "profissionais gerais" (...). No círculo exotérico, encontram-se os "leigos mais ou menos instruidos". A repercussão da estrutura geral dos coletivos de pensamento, portanto, consiste, para a ciência, 
inicialmente na formação de uma oposição entre o saber especializado e o saber popular (FLECK, [1935] 2010, p. 165).

A Fig. 1 busca representar uma comparação entre esses dois tipos de coletivos de pensamento. Nela, o coletivo de pensamento de caráter dogmático possui um círculo esotérico pequeno e restrito, separado por uma linha espessa do círculo exotérico maior - a fim de representar a dificuldade de adentrá-lo - este, por sua vez, também se separa do público externo por uma linha, porém menos espessa. Já o coletivo de pensamento de caráter democrático, como o coletivo de pensamento científico, por exemplo, possui um círculo esotérico mais amplo de especialistas gerais, com um núcleo de especialistas específicos menor, porém ambos são separados do círculo exotérico por uma linha bem fina, a fim de representar a facilidade de mobilidade entre eles. O círculo exotérico, contudo, se separa da zona externa do coletivo por uma linha um pouco mais espessa, devido à dificuldade prática para o ingresso mais livre e democrático dos indivíduos no coletivo, relacionada à educação geral desse público (SAITO, 2019, p. 27-30).
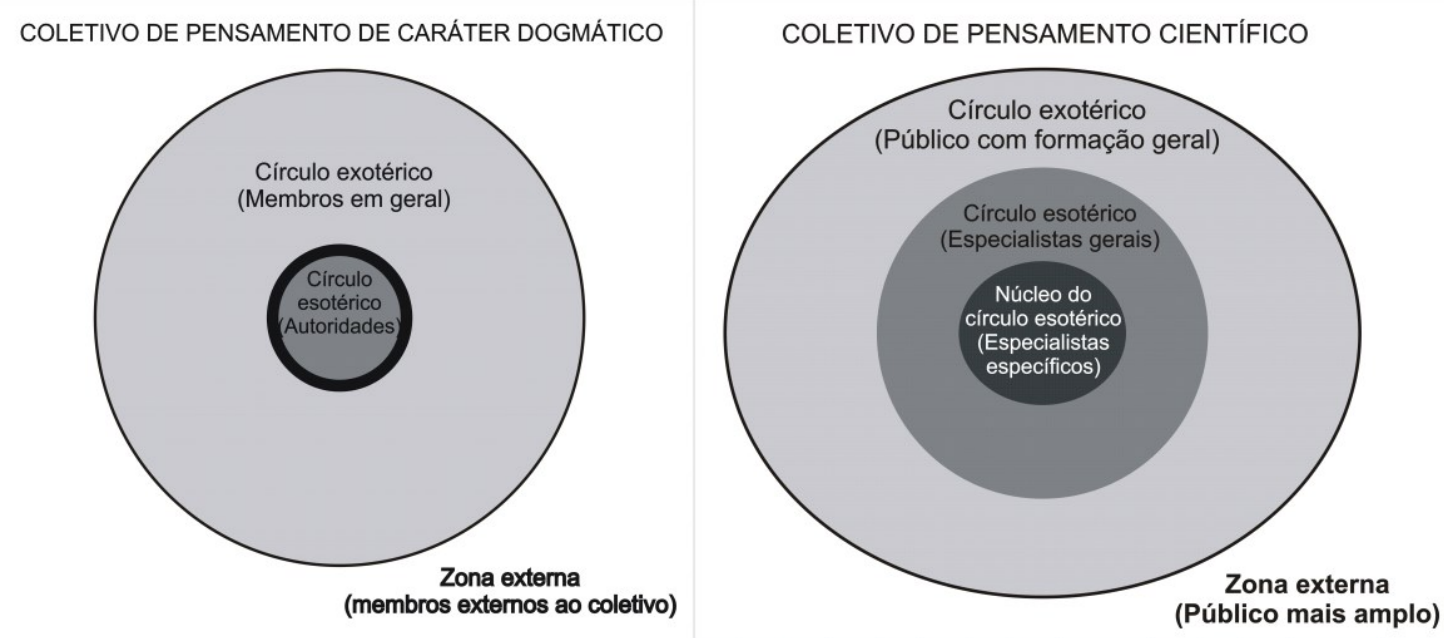

Fig. 1 - Representação comparativa entre coletivos de pensamento de caráter dogmático e democrático, como o científico, por exemplo. Fonte: SAITO, 2019.

Para Fleck, o coletivo de pensamento da ciência é democrático, pois "a ciência serve o "publico geral"” e "não há poderes secretos" nela, "não se pode referir [a ela] como uma missão obtida de círculos superiores" (FLECK, [1936] 1986, p. 105, tradução livre), ela “(...) baseia-se na organização e permanece em seu controle, recusando o privilégio de procedência divina, e se pretende acessível e útil a todos" (FLECK, [1929] 1986, p. 50, tradução livre). Ele também argumenta que:

As bordas deste círculo são abertas a todos, sua admissão não requer nenhuma cerimônia formal. A natureza democrática do coletivo científico se manifesta também no fato de que todo especialista em um determinado campo científico é um 
leigo na maioria dos outros campos, diferentemente do coletivo de pensamento religioso, onde os sacerdotes formam a totalidade da elite. (...) O sistema democrático do coletivo de pensamento científico se mostra externamente (...) em verdadeiros mecanismos democráticos, como congressos, imprensa cientifica, discussões cientificas, e no estabelecimento democrático das opiniões da "maioria dos pesquisadores”, i.e., na produção da opinião pública (FLECK, [1936] 1986, p. 105-106, tradução livre).

A partir dessa comparação entre coletivos de pensamento de caráter dogmático e democrático, é possível observar que muitos movimentos vinculados ao fenômeno da pósverdade possuem características semelhantes aos coletivos de pensamento de caráter dogmático, tais quais descritas por Fleck. Um exemplo desse tipo de movimento seriam as teorias da conspiração, as quais, em geral, são criadas a partir de algum tipo de revelação de origem exata desconhecida ou secreta, que somente um grupo restrito de pessoas pôde ter acesso e que passaram a formar as autoridades no assunto. O conhecimento referente a estas teorias não se pretende útil e acessível a todos, mas somente a seus adeptos, as suas autoridades tampouco colocam esse conhecimento em discussão por parte de seus membros e a opinião destes praticamente não é levada em conta na sua constituição. Outros movimentos similares seriam as tentativas de se criar "fatos alternativos" ou uma "ciência alternativa" aos oficiais. Essa constatação dialoga com a caracterização de Sim (2019), de que a pós-verdade seria um movimento ideológico profundamente antidemocrático em seu caráter.

Outros conceitos importantes da epistemologia de Fleck, para a caracterização dos coletivos de pensamento científicos são os acoplamentos ativos e passivos, que são conceitos pensados para distinguir a sua abordagem de abordagens "convencionalistas", nas quais o conhecimento seria uma construção social totalmente arbitrária. Os acoplamentos ativos são resultados de situações consideradas "livremente inventadas", dependentes da escolha do indivíduo, nas quais todas as possibilidades tenderiam ao "subjetivo". Já os acoplamentos passivos são resultado de situações consideradas obrigatoriamente ocorridas, independentemente da escolha do indivíduo, capazes de transmitir a impressão do "real", do "efetivo", onde todas as possibilidades tenderiam ao que se considera como "objetivo" (NOGUEIRA, 2012). Essas não consistem em categorias estáticas e separadas entre si, mas dinâmicas, inclusive, no decorrer da história e do desenvolvimento do saber, elementos passivos podem se apresentar na forma de ativos e vice-versa. Além disso, para Fleck, nenhuma proposição pode ser construída apenas com base em acoplamentos passivos, há sempre a presença de algo ativo. Contudo, uma característica que diferencia o coletivo de pensamento da ciência dos outros coletivos é a sua busca por um máximo número de elementos passivos no saber, em detrimento dos elementos ativos, isto é, a busca por "um máximo de coerção de pensamento (Denkzwang) com um mínimo de pensamento baseado na própria vontade" (FLECK, [1935] 2010, p. 144). Assim, observa-se que um importante aspecto da epistemologia fleckiana é o seu ideal de objetividade científica, o qual é central na sua concepção de ciência e na sua epistemologia social. De fato, a reconciliação do ideal 
epistêmico de objetividade com os estudos sociais da ciência consiste em uma importante vantagem da visão de Fleck em relação a outras epistemologias de abordagem social (FAGAN, 2009).

Uma vez feita essa breve apresentação de alguns conceitos da epistemologia fleckiana, é possível partir para a discussão da sua noção de verdade. Fleck acredita que nenhum conhecimento possa ser explicado unicamente pela lógica e sua fenomenologia, para ele, uma observação nunca será neutra, isenta de uma teoria que a sustente e, mais do que isso, toda observação possui uma história e está necessariamente vinculada a um estilo de pensamento. O ponto fundamental, para ele, é que não existe um padrão neutro para medir a verdade (ou importância, ou qualquer outro valor epistêmico) entre estilos de pensamento diferentes (FAGAN, 2009). Sendo assim, em contraposição ao absolutismo epistemológico, Fleck se opõe à ideia de uma verdade universalmente válida, fixa e absoluta, para a qual todos os conhecimentos, de todos os estilos de pensamento, caminhariam de forma natural. Com isso, ele descarta a ideia de verdade como uma essência a ser descoberta, para a qual o conhecimento se aproximaria assintoticamente. Em sua concepção, qualquer ideia considerada como "verdade" ou "erro" somente poderá ser considerada como tal, dentro de um determinado contexto histórico, inclusive, essa ideia poderá passar por mudanças e se atualizar ao longo do tempo. Então, ele faz a seguinte proposta, para poder definir e trabalhar com a noção de verdade:

\footnotetext{
(...) as teorias clássicas da cognição devem distinguir entre: (1) o ideal, inalcançável de verdade, (2) as "verdades" oficiais as quais "deveríamos" de alguma forma nos aproximar, (3) ilusões e equivocos. Ao mesmo tempo, elas devem admitir que não há um critério geral de verdade. (...) A epistemologia, que é a ciência dos estilos de pensamento e do seu desenvolvimento histórico e sociológico, considera que a verdade é o estágio mais avançado das mudanças do estilo de pensamento. Isso não simplifica o problema, mas o torna explorável (FLECK, [1936] 1986, p. 111-112, tradução livre).
}

Com isso, Fleck critica as epistemologias clássicas por, em geral, elas focarem apenas nos indivíduos e buscarem um ideal inalcançável de verdade, fixo, independente de qualquer contexto e, portanto, inexistente na prática. Ele também defende a adoção de uma postura pragmática, que analise a prática real dos cientistas, tal como ela de fato acontece, isto é, uma prática coletiva, dinâmica, histórica e socialmente delimitada. Dessa forma, Fleck argumenta que a investigação dos fenômenos do conhecimento e do pensamento requer a revisão da teoria do conhecimento, com conceitos epistemológicos mais flexíveis (SEIDEL, 2011). Em suas palavras: "a verdade científica se voltará de algo rígido e estacionário, para uma verdade dinâmica, com potencial de se desenvolver e humanamente criativa." (FLECK, [1960] 1986, p. 157). Assim, a verdade em Fleck procura ser uma noção em constante estado de movimento, que se modifica, de acordo com as mudanças no estilo de pensamento, ela seria, portanto, apenas a verdade permitida de se enxergar através dos limites impostos por 
este estilo. Porém, Fleck também busca se distanciar do relativismo epistemológico e de posturas céticas em relação ao conhecimento, ao afirmar que sua concepção não defende uma verdade totalmente arbitrária ou convencionalmente estabelecida, mas uma verdade para a qual a "coerção do pensamento" nos leva, a única possível dentro de um determinado estilo de pensamento.

Tal solução conforme a um estilo, somente possível de forma singular, chama-se verdade. Ela não é "relativa" ou até mesmo "subjetiva" no sentido popular da palavra. Ela sempre - ou quase sempre - é totalmente determinada dentro de um estilo de pensamento. (...) Se A e B pertencerem ao mesmo coletivo de pensamento, o pensamento é verdadeiro ou falso para ambos. (...) A verdade também não é convenção, mas um acontecimento no corte longitudinal no contexto do momento: coerção do pensamento conforme ao estilo (FLECK, [1935] 2010, p. 150-151).

Sendo assim, Fleck enfatiza que a sua consideração pelos aspectos sociais do conhecimento não resultam em abandonar, mas em reinterpretar os conceitos de verdade e objetividade. A verdade, nesse sentido, adquire um novo significado: ela não significa "verdade absoluta", mas "verdade dentro de um determinado estilo de pensamento" (SEIDEL, 2011). No entanto, apesar da possível consequência filosófica dessa concepção ser a de que cada estilo de pensamento possuiria a sua própria verdade, isso não significa que não se possa chegar a uma verdade comum às múltiplas realidades dos coletivos de pensamento. $\mathrm{Na}$ concepção de Fleck, isso seria possível através de uma epistemologia comparada, que compararia os diferentes estilos de pensamento e faria uma análise histórico-social dos seus desenvolvimentos, a fim de transpor as barreiras da coerção interna dos estilos. Para o filósofo polonês, a coerção de um estilo de pensamento particular "apenas se dissolve por meio de uma análise comparativa, revelando-se como coerção interna do estilo de pensamento" (FLECK, [1935] 2010, p. 127). Somente assim seria possível uma teoria do conhecimento coerente, daí segue a sua defesa:

A fecundidade da teoria do coletivo de pensamento se evidencia justamente na possibilidade de comparar os modos de pensar primitivo, arcaico, infantil $e$ psicótico e de analisá-los de maneira coerente. Em última instância, isso vale também para o modo de pensar de um povo, de uma classe, de um grupo qualquer. Considero o postulado de trabalhar com um máximo de experiência como a lei suprema do pensamento cientifico. Uma vez que se vislumbra a possibilidade de uma teoria comparada do conhecimento, ela se transforma em dever (FLECK, [1935] 2010, p. 94-95).

Fleck considerava a sua epistemologia comparada como um projeto interdisciplinar, que visava identificar relações que atuassem como regras entre as "forças sociocognitivas" e "comparações uniformizadas" de todos os tipos de pensamento. A ideia básica seria revelar, através da comparação e do contraste, os pressupostos que operam em um determinado 
coletivo de pensamento, para fazer com que fatos específicos pareçam evidentemente verdadeiros (FAGAN, 2009). Essa comparação seria guiada pelo princípio da "máxima experiência”, o qual Fleck considera ser um princípio científico. Com esses aspectos, o filósofo polonês defende que sua epistemologia deixaria de ser uma epistemologia especulativa ou metafísica, em busca de um ideal inatingível de verdade, e adquiriria o status de uma epistemologia científica. Inclusive, ele deixa de chamá-la de "teoria do conhecimento" e passa a chamá-la de "nova ciência do conhecimento". Portanto, para Fleck, os resultados de uma ciência comparativa do pensamento não mais consistiriam em verdades absolutas, mas em verdades sintetizadas (SEIDEL, 2011). Assim, reconhece-se que, de fato, Fleck é um construtivista social em relação à realidade objetiva e aos fatos científicos, porém, diferentemente de posturas próximas ou relacionadas à pós-verdade, ele não almeja invalidálos ou transformá-los, em vez disso, ele incorpora o ideal tradicional da objetividade científica como um método de construir e desenvolver a sua própria epistemologia, de tal forma que esse ideal passa a ser central e crucial na sua compreensão. Por isso, mais do que desvalorizar ou esvaziar a objetividade científica, a sua epistemologia busca exemplificar e explicar esse ideal epistêmico (FAGAN, 2009).

A sua epistemologia, portanto, busca acessar os demais estilos de pensamento através de mediações comunicativas específicas e busca ganhar uma legitimidade e um status de conhecimento geral, a fim de criar um coletivo de pensamento comum, livre pelo criticismo e tolerância geral (CARNEIRO, 2012, p. 150). Em suas palavras:

(...) é impossivel examinar visões independentemente da cultura de uma determinada sociedade, em uma época específica. (...) Na época em que estamos nos aproximando, uma época de sínteses e de eliminação dos particularismos, isso será inevitável. (...) A compreensão somente é possível, com base em um método comparativo: um coletivo de pensamento comum, livre por seu criticismo e geral por sua tolerância, somente será criado dessa forma (FLECK, [1937] 2007, p. 471 apud SEIDEL, 2011, tradução livre).

O criticismo é defendido por Fleck como uma característica de sua epistemologia comparada, pois esta possuiria um caráter científico e buscaria por "um máximo de coerção de pensamento", pela elaboração do "solo firme dos fatos" em detrimento do livre pensar ou, em outras palavras, pelo máximo número de elementos passivos no saber em detrimento dos elementos ativos. A tolerância geral, por sua vez, é defendida por conta do caráter democrático, típico dos coletivos de pensamento científicos, onde "o maior critério é a 'apreciação de todos'; todos podem e devem discutir cada verdade" (FLECK, [1936] 1986, p. 103, tradução livre), por sua recusa ao "privilégio de procedência divina", e porque "se pretende acessível e útil a todos" (FLECK, [1929] 1986, p. 50, tradução livre), essa epistemologia seria, portanto, uma "arte de formar uma realidade democrática e guiar-se por ela e, portanto, ser constantemente reformulada por ela também" (FLECK, [1929] 1986, p. 54, tradução livre). 
Sendo assim, é possível ver que, mesmo reconhecendo a importância das relações histórico-sociais na construção do conhecimento e a sua condição de estar em constante construção, Fleck não abre mão da objetividade científica e da noção de verdade. Para ele, mesmo que a verdade esteja em um processo permanente de mudança, e represente o "estágio mais avançado das mudanças no estilo de pensamento", ela não é totalmente arbitrária, ela caminha no sentido dirigido pela objetividade científica de sua epistemologia comparada, na busca de formar uma verdade comum aos diferentes estilos de pensamento e possui um status privilegiado, por seu criticismo e tolerância. Dessa forma, ele nega o absolutismo epistemológico e, consequentemente, a existência de "verdades absolutas" e, ao mesmo tempo, procura contornar as dificuldades do relativismo epistemológico, não colocando todos os tipos de conhecimento no mesmo patamar de confiabilidade. Além disso, ele não coloca o status privilegiado de sua epistemologia comparada como algo absoluto e estático - algo que a tornaria autorrefutável - mas como algo também em estado de constante construção, que poderia ser modificado ou reconstruído ao longo o tempo, a fim de refletir a sua própria concepção de verdade e ciência. Estes aspectos de sua epistemologia consistem em um interessante caminho para se pensar o fenômeno da pós-verdade e nos mostram que é possível conceber uma noção de verdade, que seja um caminho intermediário entre a verdade absoluta e a negação completa da existência de verdades e que, ao mesmo tempo, busque contornar os problemas do relativismo epistemológico, por mais que, eventualmente, estes não sejam completamente solucionados.

Por fim, em 1937, Fleck também chama a atenção para a "época em que estamos nos aproximando, uma época de sínteses e de eliminação dos particularismos", na qual os diferentes coletivos de pensamento estariam cada vez mais próximos e interagindo entre si. Segundo ele, nesse contexto, a busca por uma compreensão mútua e pela formação de um coletivo de pensamento comum seria inevitável. De fato, nessa época, Fleck parece ter acreditado que a aproximação entre os diferentes coletivos de pensamento pudesse levar a uma compreensão mútua entre eles, porém, talvez ele não imaginasse a dimensão das dificuldades, tensões e conflitos de interesse, que teriam que ser enfrentados nesse contexto. Na próxima seção, se buscará explorar como a epistemologia fleckiana nos fornece indícios sobre as possíveis origens e consequências dessas tensões e pistas sobre como o coletivo de pensamento da ciência poderia lidar com elas.

\section{A circulação do conhecimento científico: tensões entre popularização da ciência, democracia e epistemologia}

Conforme explorado na primeira seção deste trabalho, o fenômeno da pós-verdade surgiu de um processo de relativização da noção de verdade, que também veio acompanhado da relativização em relação a questões culturais e éticas e de um forte movimento de popularização da ciência. Através da articulação desses três processos, abriu-se margem para a elaboração de novos argumentos e estratégias, que passaram a ser utilizados em casos de 
conflitos de interesses econômicos e políticos. Entre outras consequências, isso acabou acarretando nos fenômenos de perda de credibilidade e do negacionismo da ciência, além de processos mais graves do ponto de vista da ética e da política - como a subversão, a deturpação e a falsificação dos fatos, o apelo às emoções e à retórica em detrimento da razão e o fortalecimento de movimentos antidemocráticos -, os quais resultaram na elaboração de "fatos alternativos" e de uma "ciência alternativa", característicos da pós-verdade.

Um dos principais temas abordados na epistemologia fleckiana é a circulação do conhecimento científico, em particular, ao tratar desse tema, Fleck dá destaque ao que ele denomina de ciência popular, a qual corresponde ao conhecimento científico que circula entre o público de formação geral, no círculo exotérico do coletivo de pensamento da ciência (vide Fig. 1). De fato, o filósofo polonês considera a ciência popular um problema epistemológico de extrema importância, que a teoria do conhecimento nunca chegou a analisar em profundidade. Porém, ele próprio admite, em sua obra de 1935, que o faria apenas de forma breve (FLECK, [1935] 2010, p. 165-166). Mesmo assim, Fleck detalha os processos envolvidos na popularização da ciência e chega a tocar em alguns dos possíveis problemas decorrentes dela. Sendo assim, nesta seção, serão analisados em mais detalhe esses aspectos de sua epistemologia e se refletirá sobre como essa análise poderia contribuir para pensar o fenômeno da pós-verdade.

Conforme visto na seção anterior deste trabalho, Fleck descreve a estrutura dos coletivos de pensamento da ciência (vide Fig. 1). Nela, o círculo exotérico consiste no local onde se encontra a ciência popular, e a facilidade de circulação do conhecimento e de pessoas entre os círculos exo e esotérico é uma das características que evidencia o caráter genuinamente democrático dos coletivos de pensamento científicos. No entanto, Fleck reconhece que existe uma dificuldade prática para o ingresso mais livre e democrático dos indivíduos provenientes do público externo a esse coletivo, a qual estaria vinculada à educação geral desse público.

O círculo exotérico consiste de pessoas leigas de quem nós temos uma "ciência popular" especifica. (...) Os especialistas são quase sempre recrutados dentre os especialistas mais gerais (...). Um especialista geral é quase sempre recrutado dentre as pessoas com educação geral. Por outro lado, nas condições sociais atuais, não há transições diretas entre o círculo das pessoas leigas e o "público mais amplo" (FLECK, [1936] 1986, p. 105-106, tradução livre).

Fleck também ressalta que essa estrutura proporciona a existência de uma relação entre esses círculos de mútua dependência e fortalecimento das formações de pensamento, conforme o estilo: por um lado, o saber popular confia no saber especializado e exige dele um conhecimento seguro, uma vez que ele mesmo emerge deste saber, por outro, o mesmo saber popular é que forma a opinião pública a respeito do saber especializado, cristalizando, legitimando e propagando uma imagem simplificada deste. Consequentemente, o saber popular causa um efeito retroativo sobre os especialistas e, assim, ambos contribuem para o 
fortalecimento do estilo de pensamento científico e para a formação de seu conhecimento específico (FLECK, [1935] 2010, p. 166).

Ao versar sobre a circulação do conhecimento científico, Fleck descreve as duas formas de circulação das ideias: a circulação intracoletiva, que ocorre internamente a um coletivo de pensamento, e a intercoletiva, ocorrida entre diferentes coletivos de pensamento.

De acordo com o filósofo polonês, a circulação intracoletiva pode ocorrer de várias formas, uma delas seria através da educação ou da introdução didática de um novato no coletivo de pensamento. Ela funciona como uma espécie de benção de iniciação, que introduz o sujeito aos dispositivos legais, costumes e linguagens específicas do coletivo. Fleck explica que qualquer introdução didática seria literalmente uma "condução para dentro" ou uma suave coação, análoga às iniciações conhecidas pela etnologia e pela história cultural. Por ser realizada por um iniciado no estilo de pensamento, portanto, uma autoridade, toda introdução didática em uma área envolve um tempo em que predomina um ensino puramente dogmático, até que o novato possa enxergar aquilo que "não pode ser pensado de outra maneira". Fleck, inclusive, chama a atenção que, em alguns casos, essa iniciação se torna tão difundida e natural, que "as pessoas se esquecem de tê-la recebido, uma vez que não têm contato com nenhum não iniciado" (FLECK, [1935] 2010, p. 99). Outra forma de circulação do saber intracoletiva acontece nos diálogos e trocas de ideias entre os especialistas, ou seja, entre dois participantes em posição mentalmente igual de um mesmo coletivo de pensamento. Nesse caso, Fleck explica que, entre eles:

(...) há sempre um certo sentimento de solidariedade de pensamento a serviço de uma ideia transpessoal, o que produz uma dependência intelectual recíproca entre os indivíduos e uma atmosfera (Stimmung) comum: nenhuma questão, uma vez levantada, pode permanecer, em princípio, sem efeito; cada uma é ponderada e ocupa seu lugar dentro do estilo de pensamento. Esse companheirismo (...) possibilita uma verdadeira compreensão, sendo que, sem ele, as pessoas apenas desconversam (FLECK, [1935] 2010, p. 158).

Ou seja, para Fleck, o companheirismo e a interdependência intelectual dos especialistas faz com que eles trabalhem em prol de algo maior, que é o conhecimento produzido pelo estilo de pensamento do qual eles fazem parte, e que, em princípio, transpassará e se autonomizará dos indivíduos. Esse conhecimento não é a mera soma das contribuições individuais de seus membros, mas resultado de contribuições e questões que mobilizaram todo o coletivo, direta ou indiretamente. Essa, portanto, também acaba sendo uma expressão do caráter democrático dos coletivos de pensamento científicos. Por fim, a última forma de circulação do conhecimento intracoletiva a ser citada é a relação entre o saber especializado (círculo esotérico) e a ciência popular (círculo exotérico). A ciência popular, para Fleck, é talvez o fator mais importante na circulação dos saberes, pois ela representa um fator de impacto genérico para qualquer conhecimento, uma vez que ela: 
(...) abastece a maior parte das áreas do saber de cada pessoa, e (...) o profissional mais meticuloso lhe deve muitos conceitos, muitas comparações e seus pontos de vista gerais, (...) todos utilizam em sua própria especialidade conceitos oriundos do repertório popular do saber. É em torno desses conceitos que constroem suas ciências especializadas (...). Esses elementos foram muitas vezes decisivos para o conteúdo do saber especializado, predeterminando seu desenvolvimento por décadas (FLECK, [1935] 2010, p. 165).

$\mathrm{Na}$ epistemologia fleckiana, a ciência popular consiste basicamente na ciência para não especialistas, ela se caracteriza por propagar uma imagem artificialmente simplificada da ciência especializada e explicá-la de forma esteticamente agradável e ilustrativa, omitindo os seus detalhes, restrições e complicações, mas principalmente suas polêmicas, opiniões contraditórias e os equívocos dos pesquisadores. Ela também apresenta uma avaliação apodítica dos fenômenos e das formulações, em que estes são classificados taxativamente como verdadeiros ou falsos, ou com a simples aprovação ou reprovação de determinados pontos de vista. Nela, a construção complicada e especializada dos pensamentos passa a ser apresentada como uma história simples e cristalina, como um simples fato, acarretando em uma convicção geral de que o pensamento não passa por um processo de desenvolvimento.

Ela descreve tudo como se os conceitos e as ideias existissem de antemão (...) $e$ como se sua mera aplicação "consequente" levasse à descoberta; como se outros conceitos não fossem também possíveis. Assim, a verdade é transformada numa qualidade objetivamente existente, e os pesquisadores são divididos em duas classes: em caracteres pretos, que não acertam a verdade e os brancos, que a acertam (FLECK, [1935] 2010, p. 169).

Fleck acrescenta ainda que a versão popular do conhecimento, enquanto "esquema geral", não apresenta erros conceituais ou teóricos, ou seja, ela está de acordo com a visão do estilo de pensamento, apenas não corresponde ao saber extenso do especialista. E, quanto mais nos afastamos do centro do círculo esotérico em direção à periferia do exotérico, mais essa imagem se intensifica e "o pensamento parece ser ainda mais dominado pela plasticidade (Anschaulichkeit) emotiva, que confere ao saber a segurança subjetiva da religiosidade ou do óbvio" (FLECK, [1935] 2010, p. 171). Assim, por seu caráter simples, ilustrativo e apodítico, a ciência popular apresenta o conhecimento de uma forma mais sólida, acabada e segura, formando a opinião pública. Então, com a reunião do saber popular de varias áreas, forma-se uma visão de mundo (Weltanschauung), que irá compor o pano de fundo que determinará os traços gerais do estilo de pensamento. Dessa forma, é possível considerar o tráfego de ideias entre os círculos exo e esotérico do coletivo de pensamento científico como uma via de mão dupla: por um lado, a ciência popular aparece como uma simplificação derivada, por outro, aparece como origem e pano de fundo. O movimento para fora, emigratório, que vai do centro do círculo para a sua periferia é de simplificação, enquanto o movimento contrário, imigratório, que vai da periferia para o centro é de fonte ou de retroalimentação. Assim, o 
saber exotérico serve como a base de legitimação do saber esotérico, ao mesmo tempo em que lhe fornece as noções e esquemas (linguísticos, perceptuais e mentais) básicos (OLIVEIRA, 2012). A circulação do saber intracoletiva em qualquer uma de suas formas, portanto, possui sempre o papel de fortalecer o conhecimento produzido pelo estilo de pensamento, tornando-o seguro e propagando-o.

A partir da descrição sobre a circulação intracoletiva do conhecimento científico, é possível notar que, na visão fleckiana, o fato de existir uma relação de autoridade da ciência especializada em relação à ciência popular, na elaboração do conhecimento do coletivo, não contradiz e nem o impede de possuir um caráter democrático do ponto de vista da circulação e da construção desse conhecimento. De fato, ambos - especialistas e leigos - participam nessa construção, porém majoritariamente guiados pelo saber especializado. Essa relação de autoridade é baseada na confiança, na qual o saber popular confia no saber especializado e exige dele um conhecimento seguro. Ao mesmo tempo, também se trata de uma relação de dependência mútua, pois o saber especializado também depende da visão de mundo, da legitimação, da cristalização e da propagação do saber popular. E somente através desses aspectos é que é possível o fortalecimento das formações de pensamento. Essa relação é semelhante a um sistema de governança, tal qual descrito por Nichols (2017), o qual exige e se fortalece com uma relação de confiança e dependência entre governantes e governados. Esse autor defende que, quando essa confiança é quebrada, especialistas e leigos se tornam facções conflitantes e a democracia corre o risco de cair tanto nas regras ditadas pela multidão, quanto em uma tecnocracia elitista, podendo acarretar nos fenômenos do antiintelectualismo e da ignorância voluntária, característicos da pós-verdade. De fato, Nichols (2017) descreve a era da pós-verdade como a era da "morte da competência", na qual a ampla popularização da ciência, atrelada a um processo crescente de aversão à autoridade, acarretou na crença de que a ampliação da democracia na política também poderia ser estendida para as relações com as autoridades científicas e às especialidades. Nesse processo, os cidadãos passaram a acreditar que poderiam ser especialistas em qualquer assunto e que a sua opinião deveria ser aceita como igualmente válida à dos especialistas em qualquer situação. Com isso, Nichols (2017, pp. 231-238) enfatiza que a relação entre especialistas e cidadãos gerais não é "democrática" nesse sentido, pois mantém a relação de autoridade em relação ao conhecimento científico, mas que essa relação de confiança no trabalho dos especialistas, é importante para a manutenção da própria democracia política. Dessa forma, parece ser importante manter essa estrutura de organização no coletivo de pensamento científico, conforme descrita por Fleck - uma relação de autoridade e confiança entre os saberes especializado e popular - a fim de preservar a democracia política e no próprio coletivo.

Outro aspecto que é possível observar, a partir da circulação intracoletiva do conhecimento, é que Fleck destaca a educação geral do público mais amplo como uma dificuldade prática para o ingresso mais livre e democrático dos indivíduos externos no coletivo de pensamento da ciência. Sendo assim, a educação parece ser um importante 
processo de ingresso de novos membros a esse coletivo, possibilitando com que estes possam compreender e se apropriar do conhecimento científico e do seu processo de construção, propagá-lo, desenvolvê-lo e perpetuá-lo. De tal forma que se deveria dar uma atenção especial a esse processo, principalmente no que se refere ao combate ao anti-intelectualismo e a outros efeitos nocivos da pós-verdade. De fato, o crítico da pós-verdade McComiskey (2017, p. 3844) defende que a educação pode ser uma importante arma no combate de alguns desses efeitos, além de possibilitar o desenvolvimento da criticidade e da responsabilidade social.

Por fim, outro elemento que merece destaque nessa análise é a ciência popular em si. De acordo com a descrição fleckiana, esse seria o elemento-chave de mediação entre especialistas e leigos, que forma a imagem do público geral acerca do conhecimento científico, e que, portanto, mereceria uma maior atenção por parte do seu coletivo de pensamento no combate dos efeitos nocivos da pós-verdade. De fato, Fleck chama a atenção para como a falta de conhecimento histórico sobre a construção do conhecimento científico e uma classificação simples e taxativa dos fenômenos - apenas em verdadeiros ou falsos de forma ahistórica - podem formar uma concepção pública muito superficial acerca desse conhecimento, abrindo margem para uma popularização da ciência que privilegie elementos esteticamente agradáveis e ilustrativos, em detrimento do seu detalhamento. Assim, uma ênfase maior em uma popularização da ciência e uma educação científica mais aprofundadas, que abrangessem a complexidade da construção do conhecimento científico e sua história, poderia contribuir na formação de uma visão sobre a ciência menos suscetível aos efeitos nocivos da pós-verdade. Contudo, Nichols (2017, p. 8-12) alerta para os efeitos da mercantilização da educação e do jornalismo, que têm dificultado o trabalho de popularização do conhecimento científico de uma forma mais aprofundada e crítica.

Uma vez apresentadas as características da circulação do saber intracoletiva - em especial, as referentes ao coletivo de pensamento científico - podemos partir para a descrição da circulação intercoletiva do conhecimento, a qual, segundo Fleck, possui o papel de deslocar, alterar ou transformar o estilo de pensamento.

(...) qualquer tráfego intercoletivo de pensamentos traz consigo um deslocamento ou uma alteração dos valores de pensamento (...) em toda sua escala de possibilidades: da pequena mudança matizada, passando pela mudança completa de sentido até a aniquilação de qualquer sentido. (...) Essa alteração do estilo de pensamento (...) oferece novas possibilidades de descobertas e cria novos fatos. Esse é o significado epistemológico mais importante do tráfego intercoletivo de pensamento (FLECK, [1935] 2010, p. 161-162).

Esse tipo de circulação das ideias pode ocorrer por meio de qualquer elemento que circule entre os diferentes coletivos de pensamento e, dentre os muitos existentes, Fleck destaca: as palavras e as pessoas. Para ele, as palavras possuem um status privilegiado, pois são um bem comum, que circula em qualquer coletivo. Porém, ao mesmo tempo, cada vez que passam por um determinado coletivo, elas são marcadas de alguma forma pelo seu estilo 
de pensamento, adquirindo um significado específico e podendo dar origem a novas interpretações dos termos ou, até mesmo, à completa aniquilação do seu significado original.

\begin{abstract}
A palavra como tal representa um bem intercoletivo peculiar: uma vez que a todas as palavras se lhes adere um matiz mais ou menos marcado pelo estilo de pensamento, que se altera na migração intercoletiva, elas circulam entre os coletivos sempre com uma certa alteração de seu significado. Compare-se as palavras "força", "energia" ou "teste" para um físico e para um filólogo ou um atleta (FLECK, [1935] 2010, p. 161).
\end{abstract}

A circulação de ideias intercoletiva por meio das pessoas, por sua vez, ocorre, pois nenhum indivíduo fica restrito a um único coletivo de pensamento, geralmente, as pessoas pertencem e circulam entre várias comunidades, atuando como veículo do tráfego de ideias entre elas. Contudo, Fleck chama a atenção para o fato de que, do ponto de vista social, a uniformidade do pensamento em uma comunidade, conforme o seu estilo de pensamento, é muito mais forte e sólida do que a estrutura lógica de pensamento de um único indivíduo. Pois este é capaz de separar e conviver com estilos de pensamento distintos, inclusive, suportando elementos contraditórios de forma isolada. Justamente por essa característica dos indivíduos, Fleck alerta para a impossibilidade de uma completa concordância dos vários observadores em uma comunidade, mesmo que treinados, com relação a determinado assunto. Essas novas percepções, discordâncias e choques de ideias podem acarretar em novas leituras de um mesmo objeto ou na configuração de novos objetos, que, por sua vez, possibilitam mudanças, transformações e a criação de novos estilos de pensamento (CARNEIRO, 2012, p. 49). Em geral, esse processo não ocorre subitamente, mas de forma harmoniosa e sutil, podendo se estender por um longo período de tempo.

Contudo, o filósofo polonês explica que o tráfego de ideias entre dois estilos de pensamento distintos ocorre somente quando estes possuem algum traço comum e que, quanto maior a diferença entre eles, menor será esse tráfego, uma vez que os princípios e características de um coletivo alheio sempre são vistos com certa estranheza. Sendo assim, a comunicação de ideias entre diferentes estilos de pensamento deve sempre levar em conta a linguagem, as normas e os costumes do coletivo de pensamento com quem se quer comunicar, para que possa haver entendimento mútuo. Assim, para formular uma ideia para membros de outro coletivo é preciso transformá-la de modo a torná-la próxima do seu estilo, de tal forma que um coletivo de pensamento comum será criado, intermediário entre ambos, mais pobre em conteúdo, porém mais abrangente. Fleck denomina essa forma de comunicação de propaganda (FLECK, [1936] 1986, p. 85). Segundo ele, a propaganda de uma ideia para os propósitos de um determinado coletivo de pensamento pode objetivar:

(1) a sua popularização, conforme os interesses dos leigos do coletivo; (2) informação a respeito dela, conforme os interesses de trocas entre os especialistas equivalentes; e, finalmente, (3) sua legitimação, dentro da estrutura do sistema de 
ideias do estilo, isto é, sua formulação oficial, válida para o coletivo como tal (FLECK, [1936] 1986, p. 86, tradução livre).

Porém, Fleck alerta para o fato de que, além do desejo de comunicação, a circulação de ideias intercoletiva também pode ser motivada e propulsionada por outras forças sociais, as quais podem resultar em alterações no pensamento não intencionais ou não previstas, muitas vezes, com uma completa mudança de significado, na qual apenas uma vaga e distante similaridade permanece. Fleck considera que essa circulação de ideias não intencional - do ponto de vista do coletivo de pensamento original - possui grande importância para a sociologia do pensamento e elenca alguns exemplos de efeitos que podem ser causados por esse movimento. O primeiro deles é a falsa popularização, a qual consiste na popularização acompanhada da corrupção das ideias originais como, por exemplo, quando ideias científicas são distorcidas por jornalistas. Outro possível efeito é o que Fleck chama de apoteose do pensamento, que ocorre quando a ideia se torna um motivo místico ou inconcebível, sem a devida compreensão da sua razão ou origem, sendo impensadamente cultuada. Por fim, também pode acontecer uma caricaturização do pensamento, quando a ideia se torna ridícula e motivo de escárnio, enriquecendo a impressão de um estilo completamente alheio (Fleck, [1936]1986, pp. 87-88). De fato, alguns desses efeitos chegaram a acometer a própria epistemologia fleckiana, quando esta foi distorcida por pensadores simpatizantes das políticas nazistas, conforme descrito na segunda seção deste trabalho. Fehr (2012) defende que este episódio, juntamente com os demais desafios que Fleck teve que enfrentar ao longo de sua vida, pode ter evidenciado ao filósofo polonês o ponto no qual o caráter democrático da ciência encontra os seus limites.

A primeira coisa que é possível de se observar, a partir da análise fleckiana sobre a circulação intercoletiva do conhecimento, é que esse tipo de circulação consiste no processo que possibilita as transformações e alterações no estilo de pensamento do coletivo da ciência. Contudo, elas podem ocorrer tanto no sentido do desenvolvimento do próprio conhecimento científico - a partir de diálogos com outras áreas de conhecimento, possibilitando novos olhares para os fenômenos -, quanto no sentido de sua subversão ou, em última instância, de sua aniquilação - a partir dos efeitos de outras forças sociais com esse interesse.

Fleck também ressalta que ambos os sentidos dessas transformações podem ocorrer por meio da circulação das palavras, as quais adquirem diferentes significados, ao circularem entre os diferentes coletivos de pensamento. Nesse sentido, Fleck antecipa uma parte da importância que passou a ser dada ao papel da linguagem nas transformações dos significados e do conhecimento, por parte dos filósofos pós-estruturalistas da segunda metade do século XX, como Derrida, Lyotard e outros. Contudo, Fleck também dá destaque a um elemento que poderia ser uma alternativa para responder algumas críticas ${ }^{3}$ que esses filósofos sofreriam

\footnotetext{
3 Algumas dessas críticas seriam: uma ênfase muito grande na importância da linguagem, desconsiderando outros elementos na formulação dos discursos e do conhecimento, e a ênfase na incomensurabilidade entre os diferentes grupos sociais, ressaltando a impossibilidade de se estabelecer uma comunicação comum entre eles.
} 
posteriormente: a circulação das pessoas e o seu pertencimento a diferentes coletivos de pensamento. Ao dar destaque a esse elemento, ele abre a possibilidade de levar em conta a comunicação e os possíveis conflitos de interesse entre esses coletivos, na transformação do conhecimento científico, de tal forma a poder considerar as forças políticas de alguns grupos sociais nesse processo.

Inclusive, ele ressalta que é mais comum as pessoas fazerem parte de coletivos de pensamento bem distintos entre si, do que de coletivos semelhantes, pois, nesse caso, a separação entre os estilos de pensamento afins e seus elementos contraditórios se torna difícil, senão impossível (FLECK, [1935] 2010, p. 162). Isso faz com que essas pessoas atuem como veículos de comunicação entre as comunidades distintas e intensifiquem as possibilidades de conflitos de interesse e de se estabelecer relações contraditórias. Além disso, ele também ressalta que a uniformidade do pensamento é mais estável nos coletivos de pensamento do que no individuo, e que os estilos de pensamento alheios são sempre vistos com uma certa estranheza (FLECK, [1935] 2010, p. 160-161), o que cria a necessidade de adequar a linguagem para que haja comunicação entre eles. Dessa forma, em um caso de conflito de interesses entre estilos de pensamento rivais, os propósitos da popularização e da legitimação do conhecimento em diferentes coletivos de pensamento, motivados por forças sociais e políticas diversas, podem gerar intencionalmente as mudanças de significado citadas por Fleck (falsa popularização, apoteose do pensamento e caricaturização do pensamento). E, de fato, parece ser justamente esse processo que se observa no fenômeno da pós-verdade.

Levando-se em conta os episódios da vida de Fleck - incluindo-se o fato de que ele deixa de mencionar o caráter democrático da ciência, em seus escritos posteriores a 1939 -, esses conflitos de interesse e a possibilidade deles transformarem o conhecimento científico no sentido de sua subversão e, até mesmo, de sua aniquilação, fazem com que esse pareça ser, de fato, o limite da possibilidade de um coletivo de pensamento científico de caráter completamente democrático, que aceitasse de bom grado qualquer tipo de ideias e pessoas de interesses sociais e políticos diversos. Isso porque, conforme os críticos da pós-verdade ressaltam, isto poderia significar o fim da própria característica democrática desse coletivo e, consequentemente, da própria ciência (NICHOLS, 2017; SIM, 2019).

Talvez por conta disso, é que a argumentação de Fleck em defesa de sua epistemologia comparada de caráter científico, muitas vezes, apresenta uma forte conotação política e ética (SEIDEL, 2011; CARNEIRO, 2012). Assim, o status privilegiado que o filósofo polonês fornece para a sua epistemologia comparada é justificado não apenas por considerações epistemológicas, de caráter lógico e/ou fenomenológico, mas principalmente com base nas consequências políticas e normativas que ela supostamente pode ter (SEIDEL, 2011), as quais também podem recair sobre a ciência e sobre a epistemologia como área do conhecimento. Para Fleck, a sua epistemologia comparada - baseada no princípio da "máxima experiência", atrelado às normas da objetividade científica e à relação de autoridade e confiança entre especialistas e leigos - e o seu desejo de formar um coletivo de pensamento 
comum - "livre por seu criticismo geral e por sua tolerância" - poderiam dissolver a unilateralidade e as limitações de determinados estilos de pensamento de caráter dogmático ou antidemocrático. Com isso, seria possível promover a tolerância, a solidariedade, a compreensão mútua e manter a confiança nos conhecimentos especializados, através dos estudos comparativos e de discussões reais e genuínas entre pessoas de diferentes coletivos de pensamento. De fato, por vezes, Fleck parece acreditar que o sucesso de sua epistemologia comparada seria, de alguma forma, uma necessidade histórica, a fim de evitar a exploração do conhecimento em prol de objetivos viciosos e nos imunizar "contra a submissão absoluta a propaganda", as quais poderiam resultar em consequências políticas devastadoras (SEIDEL, 2011). Sendo assim, as limitações do caráter democrático do coletivo de pensamento da ciência - através da não aceitação de ideias e posturas contrárias ao desenvolvimento dela própria, que poderiam ameaçar a sua própria existência - e a defesa de Fleck por uma epistemologia comparada de caráter científico, com todos os aspectos descritos, parecem ser não somente um interessante caminho para se enfrentar os efeitos nocivos do fenômeno da pós-verdade, mas também uma necessidade histórica para a preservação da ciência e da democracia.

\section{Considerações finais: possíveis implicações para a Ciência e para a Educação Científica}

$\mathrm{O}$ advento do fenômeno da pós-verdade tem se mostrado um processo complexo, multifacetado e ambíguo. Do ponto de vista filosófico, surgiu de um processo importante de questionamentos sobre a existência de verdades absolutas e ahistóricas, porém, ao mesmo tempo permitiu com que o ceticismo, o relativismo epistemológico e aspectos antiéticos relacionados à retórica e à subversão dos fatos emergissem e ganhassem força na sociedade. Do ponto de vista histórico-social, surgiu de um importante e longo processo de democratização do acesso ao conhecimento e de contato e convivência com outras culturas, que mostrou a importância do reconhecimento da diferença na formação dos julgamentos e crenças. Contudo, esse processo também veio acompanhado da relativização em relação a questões éticas, da intensificação dos conflitos de interesses e da mercantilização da informação e do conhecimento. Do ponto de vista político, todos esses aspectos alertam para os perigos e efeitos nocivos que a pós-verdade pode trazer para as sociedades democráticas, pois possibilitaram o surgimento de movimentos de caráter profundamente antidemocrático, como o anti-intelectualismo, o negacionismo e a ignorância voluntária.

Diante dessa complexidade, neste trabalho, optou-se por explorar esse fenômeno a partir de uma perspectiva que dialogasse com todos esses problemas e debates: a epistemologia de Ludwik Fleck. Isso porque essa epistemologia propõe uma noção de verdade que se pretende um caminho intermediário entre o absolutismo e o relativismo epistemológicos e porque analisa a circulação do conhecimento e os seus possíveis efeitos, levando-se em conta as especificidades dos meios e comunidades em que circula e o seu 
contexto histórico-social. A partir dessa análise, de fato, constatou-se que a concepção de verdade fleckiana como o "estágio mais avançado das mudanças no estilo de pensamento" e a proposta de uma epistemologia comparada de caráter científico, ao criticar tanto a verdade absoluta quanto a negação completa da existência de verdades, parecem ser uma alternativa interessante para se pensar as críticas de ambos os lados vinculados ao advento do fenômeno da pós-verdade.

A partir da epistemologia e dos conceitos fleckianos, também foi possível observar que diversos movimentos vinculados a esse fenômeno - como as teorias da conspiração e os "fatos e ciência alternativos" - possuem um caráter mais próximo dos coletivos de pensamento de caráter dogmático do que dos de caráter democrático, o que dialoga com as caracterizações de diversos autores críticos da pós-verdade.

Já a partir da análise de Fleck sobre a circulação do conhecimento científico intracoletiva (internamente a um coletivo de pensamento), foi possível observar que o filósofo polonês, ao descrever a estrutura dos coletivos de pensamento da ciência, revela a existência de uma relação de autoridade, confiança e dependência mútua entre o saber especializado e o saber popular, semelhante a um sistema de governança. Porém, a relação de autoridade do primeiro em relação ao segundo não contradiz e nem impede os coletivos científicos de possuírem um caráter democrático, do ponto de vista da circulação do conhecimento e de participação na sua construção, uma vez que um se alimenta do outro. Aparentemente, essa relação é importante de ser mantida nesse formato, a fim de preservar a manutenção da própria democracia política e evitar o surgimento de movimentos de caráter dogmático ou antidemocrático, como o anti-intelectualismo e a ignorância voluntária, típicos do fenômeno da pós-verdade.

No entanto, até mesmo o caráter democrático do coletivo de pensamento da ciência possui limitações. Isso porque, a partir da análise de Fleck sobre a circulação do conhecimento intercoletiva (entre os diferentes coletivos de pensamento), foi possível constatar que esse tipo de circulação é que consiste no processo que possibilita as transformações e alterações no estilo de pensamento da ciência. Essas transformações podem ocorrer tanto no sentido do desenvolvimento do conhecimento científico, quanto no sentido da sua subversão ou, em última instância, da sua aniquilação. Isso significa que, em contextos histórico-sociais adversos ou de conflitos de interesse, as diversas forças sociais e políticas podem subverter os propósitos da popularização e da legitimação do conhecimento científico nos diferentes coletivos de pensamento, gerando mudanças de significado nesse conhecimento de forma não intencional ou não desejada. Inclusive, a própria trajetória pessoal e profissional de Fleck nos forneceu um exemplo de como um conhecimento pode ser apropriado, usurpado e utilizado para fins antidemocráticos. Isso pode acontecer porque existem diversos elementos que circulam entre os diferentes coletivos de pensamento - como as palavras e as pessoas, por exemplo - e que acabam atuando como veículo do tráfego de ideias entre eles. Dessa forma, parece ser importante atentar-se para os conflitos de interesse e 
limitar a disseminação de ideias contrárias ao desenvolvimento da ciência, que podem ameaçar o seu caráter democrático e a sua própria existência. Para isso, Fleck propõe a sua epistemologia comparada, baseada no princípio da "máxima experiência", nas normas da objetividade científica e na manutenção da relação de autoridade e confiança entre especialistas e leigos. Essa proposta procuraria dissolver a unilateralidade e as limitações de determinados estilos de pensamento de caráter dogmático ou antidemocrático e promover a tolerância, a solidariedade e a compreensão mútua, através de estudos comparativos e de discussões reais e genuínas entre pessoas de diferentes coletivos de pensamento. E, de fato, esse parece ser não somente um caminho interessante, mas uma necessidade histórica para a preservação da ciência e da democracia.

Por fim, Fleck também destaca a educação geral do público mais amplo, como uma dificuldade prática para o ingresso mais livre e democrático dos indivíduos externos no coletivo de pensamento da ciência, e a ciência popular, como a principal formadora da imagem do público geral acerca do conhecimento científico. Sendo assim, foi possível notar que tanto a educação científica quanto a popularização da ciência mereceriam uma maior atenção por parte dos coletivos de pensamento da ciência, pois ambas podem consistir em importantes armas no combate de alguns dos efeitos nocivos da pós-verdade - como antiintelectualismo, o negacionismo e a ignorância voluntária -, além de possibilitar o desenvolvimento da criticidade e da responsabilidade social nos estudantes e cidadãos em geral. Porém, para isso, elas precisariam ser realizadas de uma forma mais crítica e historicamente contextualizadas. Pois, devido aos efeitos da mercantilização da educação e do jornalismo, entre outros fatores, elas têm sido realizadas de forma muito taxativa em relação aos fenômenos e ao conhecimento e privilegiado elementos esteticamente agradáveis e ilustrativos, em detrimento do seu detalhamento. Sendo assim, uma popularização da ciência e uma educação científica, que abrangessem a complexidade da construção do conhecimento científico e a sua construção histórica, poderiam contribuir melhor para a formação de uma visão sobre a ciência menos suscetível aos efeitos nocivos da pós-verdade.

\section{Agradecimentos}

A autora agradece ao Prof. Dr. Ivã Gurgel e aos pareceristas pelos comentários e sugestões valiosas para a realização deste trabalho.

\section{Referências bibliográficas}

CARNEIRO, J.A.C. A teoria comparativa do conhecimento de Ludwik Fleck: comunicabilidade e incomensurabilidade no desenvolvimento das ideias científicas. 2012. 194f. Dissertação (Mestrado) - Faculdade de Filosofia, Letras e Ciências Humanas, USP, São Paulo. 
FAGAN, M.B. Fleck and the social constitution of scientific objectivity. Studies in History and Philosophy of Biological and Biomedical Sciences, v. 40, p. 272-285, 2009.

FEHR, J. “...the art of shaping a democratic reality and being directed by it ..." - philosophy of science in turbulent times. Studies in East European Thought, v. 64, p. 81-89, 2012.

FLECK, L. On the crisis of 'reality' [1929]. In: COHEN, R. S.; SCHNELLE, T. Cognition and Fact: Materials on Ludwik Fleck. Dordrecht: D. Reidel Publishing Company, 1986. p. 47-58.

FLECK, L. The problem of epistemology [1936]. In: COHEN, R. S.; SCHNELLE, T. Cognition and Fact: Materials on Ludwik Fleck. Dordrecht: D. Reidel Publishing Company, 1986. p. 79-112.

FLECK, L. Crisis in science [1960]. In: COHEN, R. S.; SCHNELLE, T. Cognition and Fact: Materials on Ludwik Fleck. Dordrecht: D. Reidel Publishing Company, 1986. p. 153-158.

FLECK, L. Science and Social Context [1939]. In: LÖWY, I. The Polish School of Philosophy of Medicine: from Tytus Chalubinski (1820-1889) to Ludwik Fleck (1896-1961). Dordrecht, Boston, London: Kluwer Academic Publishers, p. 249-256, 1990.

FLECK, L. Gênese e desenvolvimento de um fato científico: introdução à doutrina do estilo de pensamento e do coletivo de pensamento [1935]. Tradução: Georg Otte e Mariana Camilo de Oliveira. Belo Horizonte: Fabrefactum, 2010.

FULLER, S. Post-Truth: Knowledge as a Power Game. London: Anthem Press, 2018.

GOLINSKI, J. Making natural knowledge: constructivism and the history of science with a new preface. Chicago; London: The University of Chicago Press, 2005.

LÖWY, I. The Polish School of Philosophy of Medicine: from Tytus Chalubinski (18201889) to Ludwik Fleck (1896-1961). Compiled, translated and introductions by the author. Dordecht: Reidel, 1990.

MCCOMISKEY, B. Post-Truth Rhetoric and Composition. Logan: Utah State University Press, 2017.

MCINTRE, L.C. Post-truth. Cambridge, MA: MIT Press, 2018. 
NICHOLS, T. The Death Of Expertise: The Campaign Against Established Knowledge and Why it Matters. New York: Oxford University Press, 2017.

NOGUEIRA, F.S. Ciência e linguagem: Fleck e o estilo de pensamento como rede de significados na ciência. 2012. 134f. Dissertação (Mestrado) - Faculdade de Filosofia e Ciências Humanas, UFMG, Belo Horizonte.

OLIVEIRA, B. J. Os circuitos de Fleck e a questão da popularização da ciência. In: CONDÉ, M. L. L. (Org.). Ludwik Fleck: estilos de pensamento na ciência. Belo Horizonte: Fino traço, 2012. cap. VI. p. 121-144.

SAITO, M.T. A gênese e o desenvolvimento da relação entre física quântica e misticismo e suas contribuições para o ensino de ciências. 2019. 348f. Tese (Doutorado) - Instituto de Física, USP, São Paulo.

SCHÄFER, L.; SCHNELLE, T. Introdução: fundamentação da perspectiva sociológica de Ludwik Fleck na teoria da ciência. In: FLECK, L. Gênese e desenvolvimento de um fato científico: introdução à doutrina do estilo de pensamento e do coletivo de pensamento. Tradução: Georg Otte e Mariana Camilo de Oliveira. Belo Horizonte: Fabrefactum, 2010. p. 3-4.

SEIDEL, M. Relativism or Relationism? A Mannheimian Interpretation of Fleck's Claims About Relativism. Journal for General Philosophy of Science, v. 42, p. 219-240, 2011.

SIM, S. Post-Truth: Scepticism \& Power. Cham: Palgrave Macmillan, 2019.

TALLIS, B. Living in Post-Truth: Power/Knowledge/Responsibility. New Perspectives, v. 24, n. 1, p. 7-18, 2016.

ZACKARIASSON, U. Introduction: Engaging Relativism and Post-Truth. In: STENMARK, M., FULLER, S., ZACKARIASSON, U. (Eds.). Relativism and Post-Truth in Contemporary Society: Possibilities and Challenges, Cham: Palgrave Macmillan, p. 1-17, 2018.

(cc) BY-Ne-ND Direito autoral e licença de uso: Este artigo está licenciado sob uma Licença Creative Commons. 